\title{
Brand Selection Dimensions in Family Buying of Personal Care Products
}

\author{
Sakshi SHARMA ${ }^{*}$, Maninder SINGH $^{* *}$
}

Received: September 25, 2018

Revised: April 22, 2019

Accepted: April 30, 2019.

\begin{abstract}
The aim of present study endeavors to uncover the dimensions of brand selection in buying of personal care products. The results confirmed four dimensions of brand selection for each studied product i.e. shampoo (Variety and Value Seeking, Functionality-Hair Care, Brand Adherence and Habitual Selection), toilet soap (Value \& Variety Seeking, Functionality, Significance of Image and Time and Friend's Influence) and toothpaste (Functionality-Oral Care, Value Seeking, Outer Directed Brand Adherence and Parental Influence). Another important finding of this study is that dimensions of brand selections have significant gender differences. Interestingly, this study shows that males are found to be more variety, value and functionality seekers in buying of personal care products as compared to their counterparts. Females are found to be more brands adhered and influenced by friend and parents. The paper offers insights that the variety and value seeking brand selection dimensions are highly strong brand selection dimensions for all studied products. As personal care products buyers have shown great interest in variety and value seeking, the study suggests that promotional efforts like sales promotions and advertising can play a vital role in marketeering of these products for a new entrant as well as for established marketers.
\end{abstract}

Keywords: Brand Selection, FMCGs, Personal Care Products, Non-durable, Marketing, Family Buying

JEL Code Classification: L67, M13

UDC: 339.133 .017

DOI: https://doi.org/10.17015/ejbe.2019.023.03

\footnotetext{
*Assistant professor, Khalsa College Amritsar, Research Scholar at Inder Kumar Gujral University, Kapurthala, India. E-mail: shanumunish@gmail.com

**Associate Professor, Amritsar College of Engineering, Amritsar, India. E-mail:

Maninder_gill13@yahoo.com

Copyright (C), 2015 International Ataturk Alatoo University.
} 


\section{Introduction}

Consumer decision making has traditionally centered on studying how information about all alternatives are analyzed to decide the final choice. Marketing firms always aspire that their product is perceived not only as a product but also as a brand with a distinct identity. Mostly consumer selects first purchase on the base of crude heuristics, which further gets refined and stabilized over repeated trials or purchase occasions and he/she learns to choose one product over other (Deshpande, Hoyer \& Jeffries, 1982). These consumer preferences are considered as his/her 'Loyalties' (Wheeler, 1974). Copeland (1923) appears to be the first to mention the concept of brand loyalty and since then over two hundred definitions of brand loyalty have appeared in the literature (Jacoby and Chestnut, 1978). According to Jacoby and Chestnut (1978), brand loyalty is defined as the biased behavioral response (systematic tendency to select a certain brand or group of brands), expressed over time (purchase consistency during a certain time span), by some decision making unit (an individual, a household, a firm), with respect to one or more alternative brands out of a set of such brands (there must be an opportunity to choose among alternatives) and is a function of psychological (decision making and evaluative) process resulting in brand commitment. This definition stressed on the biased behaviour of buyer towards selecting a certain brand out of many alternative brands and considers it as a psychological process.

It has been observed that for common, repeat purchase products (fast moving consumer goods), rather than extensive inside store processing, simple decisions are made based on perception of performance of that particular product (Leong, 1993).The relationship between product type, brand selection and loyalty is also supported by many studies (Cunningham, 1956; Carmen, 1970; and Palumbo and Herbig, 2000) which suggests that for different products, buyers have different brand selection criteria. Rundle-Thiele and Bennett (2001) explored the issue of the importance of product category and indicated that consumable (fast moving consumer goods) markets show signs of divided loyalty and are characterized by multi brand selection. As per the received wisdom, fast moving consumer goods are thought to have multi-brand loyalty and buyers are prone to select multi brands, the present paper aims to explore the brand selection dimensions of personal care products (a segment of FMCGs products) to insight the brand selection behaviour of personal care product buyers.

\section{Literature Review}

\subsection{Brand Selection}

The capability to attract consumers towards its brand decides the future of any firm. It is critical for every business to retain its current customers, and to make them loyal towards its brand for survival and growth of the company. Leong (1993) investigated consumer decision making for common, repeat -purchase products 
and compared it across countries. The study revealed that buyer made very less across and with-in comparisons for brand selection of detergent as well as shampoo. In opposite to this, in product wise comparison of detergent and shampoo, significant difference was observed between both products for withinbrand comparison. Further this study explored four dimensions of brand selection namely performance tactics, price tactics, normative tactics and affect tactics. Performance tactics (functional aspects) found to be the main consideration in brand selection. Finally, this study concluded that decision making processes across cultures are found to be almost similar, whereas, across product classes (shampoo and detergent) some dissimilarity has been observed in purchase decision making process. Bhatt and Reddy (1998) explored the phenomenon of the symbolism and functionality in brand image and developed scales to classify a brand as symbolic or functional. The study explored distinction between functional and symbolic constructs and further, hinted that symbolic construct supposed to be two dimensional i.e. prestige of brand and user's personality expression. Finally, in conclusion study stated that rating of symbolic brands on functional scale and rating of functional brands on symbolic scale was found to be at mid points, so in against to an earlier study (Park et al., 1986) where the author suggested to choose either appeal, this study found possibility to use both appeals (functional and symbolic) in selection of a particular brand. Wood (2004) tried to identify the dimensions that underpin brand selection among 18-24 years olds across six product categories (toilet soap, toothpaste, coffee, breakfast cereal, trainers, and jeans). This study explored two dimensions in selection of toilet soap-outer directed brand loyalty and value seeking. For selection of toothpaste the study explored two dimensions - habitual brand loyalty and value seeking. The study explored two dimensions of selection of coffee-habitual brand loyalty and value. For breakfast cereals, three dimensions were explored-value and variety and outer directed and inertia. For trainer three dimensions were revealed i.e. outer directed brand loyalty, bargain oriented and variety. For jeans the study revealed three dimensions - value seeking, outer directed and image variety seeker. At the same time, Soni (2004) found that durability was the most considered dimension in brand selection of four products - refrigerator, television, car and two wheelers whereas, status symbol was found to be the least considered dimension in brand selection of three products - refrigerator, television and two-wheeler. For selection of car, ease of use was the least considered dimension. Further, Wood (2007) studied functional and symbolic attributes of brand selection and loyalty of customers of FMCG products in U.K within 18-24 age groups. The study investigated the brand loyalty behavior across different product categories and found significant differences in degree of brand loyalty exhibited by respondents. Moreover, study explored the dimensions that drive loyalty behavior within same age group and found that dimensions of brand selection varied across product types. In this study Brand Heritage has been found to be the most influential dimension in selection of toothpaste and coffee products. Value and variety were 
considered most vital attribute in brand selection of cereals. Mise et al. (2013) investigated and compared the African and the Asian buying behavior in soft drink markets. The study found that in both soft drink markets, brand loyalty exerted a positive significant relationship with product quality, product satisfaction, product price, product promotion and brand name however, it was noted that Indian consumers were more price sensitive and moreover, considered quality and satisfaction more influential than the Kenyan consumers. Further, the study suggested that Indian customers were more brand name sensitive and Kenyan consumers were pushed more by promotions. On the overall, the study concluded that among all factors quality was considered most influential by Indian customers whereas, promotion was the strongest factor for Kenyan customers. Pradhan and Mishra (2015) studied the brand awareness and preference of rural consumer for fast moving consumer goods with special reference to toilet soaps and further tried to explore the influence of demographic factors on buying behaviour. The study revealed that that there was no significant relation between age and brand preference moreover, male and females showed same attitude towards different brands of soaps. It was found that there was no statistically significant relation between family type and brand preference. Further, interestingly, the study noted significant relation between occupation and brand preference and besides this, statistically significant relation between income and brand preferences was also observed. Lee (2018) established a link between consumption section criteria and intension of consumer to re-buy that same brand for smart phone. The study found that price, durability and designing factors of brand selection resulted in brand switching, whereas, favorability and interest in brand contributed to repurchase of that brand.

\subsection{Family Buying}

Most of the time actual purchase of personal care products for family use is done by one person only, but always there is more than one person behind the decision making process of those products (Yakup \& Sevil, 2011). In earlier studies related to role of family members in decision making process, researchers confirmed that there is role specialization within family while buying goods but, most of the studies considered husband and wife dyad only as a decision making unit (Davis, 1970; Davis, 1976 and Burns \& Granbois, 1980). Moreover, husband was considered the most dominant member in family decision making due to his financial power (Cunha \& Neto, 2015). Many researchers (Ferber and Chao Lee, 1974 and Spiro, 1983) argued that financial contribution of working women in household budgets and enhancement in alternative evaluation power increased the influence of women in decision making of households. Soni (2004) argued that mostly household decisions were taken by husband only or dyad (husband and wife) as a joint. However, Purchasing power of adolescent has increased noticeably in last few years (Bristol, 2001; Wu et al., 2010). Many other researchers (e.g. Beatty \& Talpade, 1994; Jenkins, 1980; Lee \& Beatty, 2002; Thomson et al., 2007; 
Wang et al., 2007; Watne \& Brennan, 2011) acknowledged the importance of children in family decision making. Harcar et al. (2005) attempted cross cultural comparisons of husband and wife decision making roles in purchase of various goods and services in unlike environments of five countries. This study revealed high degrees of similarities in family purchasing decision roles among the five countries.

Moreover, as per the received wisdom, except some studies (Pradhan and Mishra, 2015), many studies have been found to support the view that there are significant differences across age and gender in brand selection of products (Tifferet \& Herstein, 2012; Gasiorowska, 2011; Barber, Almanza \& Donovan, 2006; Gasiorowaska, 2003; Dholakia, 1999) From the foregoing discussion, it has been seen that most of the previous research is concerned with brand loyalty of fast moving consumer goodsor durable goods (Mise et al., 2013; Wood 2007; Soni, 2004), but there is dearth of research that has taken brand selection dimensions to understand the brand selection behaviour of buyers for joint use personal care products. Therefore, the present study endeavors to fill the gap in literature by examining brand selection dimensions of joint use personal care products in India through primary responses of husbands/wives, who select these products for family use.

\section{Hypothesis Development}

Received wisdom showed that men do not like shopping and are lesser active in this area than women. Women exhibit more brand commitment, hedonic consumption and impulse buying as compared to male customers. Furthermore, some researchers have stressed that females regard both utilitarian and symbolic values as more important determinants while buying products than their male counterparts. Nevertheless, this insight is not only based on stereotypes but consumer behaviour literature finds confirmation of it in various research results (Tifferet \& Herstein, 2012; Gasiorowska, 2011; Gasiorowaska, 2003; Dholakia, 1999). It is considered that for the selection of basic goods, the majority of shopping products are women's domain (Bakewell \& Mitchel, 2004, Dholakia, 1999, Kollat \& Willet, 1967). According to Kollat and Willet (1967), impulse buying differences has not been caused by gender, but by the overall frequency of purchasing. The authors have suggested that if the frequency of purchases is same for men and women, the difference would disappear. Further Barber et al (2006), suggested that females and young respondents (21 to 30 years) are found to be more concerned about selecting product (wine) brand. Therefore, the present study taking into account the primary responses of personal care products customers, explores the differences in responses of buyers (male/female and younger/older) with respect to brand selection dimensions of personal care products i.e. shampoo, toilet soap and toothpaste. Consequently, in order to identify aforesaid differences, MANOVA has been applied and for this purpose, following hypotheses have been framed. 
$\mathrm{H} 1$ : There are significant differences between customers of age groups (30-40 years and 41-50 years) across dimensions of brand selection of shampoo.

$\mathrm{H}$ 2: There are significant differences between male and female customers across dimensions of brand selection of shampoo.

H3: There are significant differences between male and female customers of age groups (30-40 years and 41-50 years) across dimensions of brand selection of shampoo.

$\mathrm{H} 4$ : There are significant differences between customers of age groups (30-40 years and 41-50 years) across dimensions of brand selection of toilet soap.

H5: There are significant differences between male and female customers across dimensions of brand selection of toilet soap.

H6: There are significant differences between male and female customers of age groups (30-40 years and 41-50 years) across dimensions of brand selection of toilet soap.

H7: There are significant differences between customers of age groups (30-40 years and 41-50 years) across dimensions of brand selection of toothpaste.

H8: There are significant differences between male and female customers across dimensions of brand selection of toothpaste.

H9: There are significant differences between male and female customers of age groups (30-40 years and 41-50 years) across dimensions of brand selection of toothpaste.

\section{Research Methodology}

\subsection{Data Collection and Sample}

The universe of the study consists of three districts-Amritsar (29.9\%), Jalandhar (28\%) and Ludhiana (42.1\%), incorporating sample as per population proportion with respect to these three districts (Census, 2011). These three districts comprise people from different demographic profiles. A non-random convenience sampling design was adopted to approach respondents. To study the involvement of customers of joint use personal care products, families including husband and/or wife, grandparents and at least one eight or above eight years old child were approached. As per the suggestion of many researchers to depict buying behaviour on an aggregate basis, the responses from either spouse are sufficient (Szybillo, 1977; Davis, 1970, 71), so only one spouse, either husband or wife was selected as respondent in this study. Rapid Survey on Children (RSOC, 2013-14) by UNICEF noted that average age of marriage is $\mathbf{1 9 . 9}$ for female and 23.4 for males in Punjab, so the age of respondents was restricted to be minimum of thirty years with a view to have a minimum eight years old child.

Total 720 questionnaires were distributed to families with different demographic characteristics; of this only $542(75.27 \%)$ questionnaires were found to be usable. 
Data were collected in time period of approximately five months i.e. February, 2018 to June, 2018. Out of total 542 respondents, 333 (61.4\%) were females and 209 (38.6\%) were males. Respondents were categorized into two age bands i.e. 30 to 40 years (36\%) and 41 to 50 years (64\%). Most of the respondents reported their monthly household income to be in the range of USD572837 (47.4\%). More than one fourth of respondents (25.6\%) were earning more than USD837 monthly, whereas approximately one fifth (20.1\%) respondents reported to be their monthly income in the range of USD293-572.

\subsection{Operationalization of Brand Selection Dimensions}

A well structured questionnaire was utilized to explore the brand selection dimensions of personal care product - shampoo, toilet soap and toothpaste. In order to measure the brand selection dimensions of these products, sixteen variables have been used on the basis of previous literature (Pradhan and Mishra, 2014; Rishi, 2013; Wang, 2007; Kumar and Advani, 2005). All of these variables have been measured on five-point scale with ' 5 ' indicating 'strongly agree' (SA), and ' 1 ' indicating 'strongly disagree' (SD).

Data have been analyzed using Descriptive Statistics, Exploratory Factor Analysis (EFA) and Multivariate Analyses of variance (MANOVA) through SPSS 19.0.

\section{Analysis}

\subsection{Underlying dimensions of brand (shampoo, toilet soap and toothpaste) selection-Exploratory Factor Analysis (EFA)}

Exploratory Factor Analysis (EFA) with Varimax rotation explored four factors (with an Eigen value of one or more) solution, for each product-shampoo (KMO= $0.848)$, toilet soap $(\mathrm{KMO}=0.860)$ and toothpaste $(\mathrm{KMO}=0.859)$ to explore the brand selection dimensions of personal care product buyers. Table 1 illustrates the brand selection dimensions of personal care products (shampoo, toilet soap and toothpaste) and further, appropriate names are assigned based on the nature of the variables loaded on a particular factor. In brand selection of shampoo the first dimension - Variety and Value Seeking, combines four variables (multi brands, price, promotions and novelty and variety) and results as strongest dimension of brand selection followed by Functionality-Hair care, Band Adherence and Habitual Selection dimensions of brand selection. Moreover, the strongest dimension in brand selection of toilet soaps has been recognized as Value \& Variety Seeking followed by Functionality, Significance of Image and Time and Friends Influence dimensions respectively. Interestingly, for brand selection of toothpaste the strongest dimension i.e. Functionality-Oral Care which includes six variables (tooth decay, cavity, whitening, freshness, gum protection and taste) is followed by Value Seeking, Outer Directed Brand Adherence and Parental Influence dimensions of brand selection. 
Sakshi SHARMA \& Maninder SINGH

Table 1. Brand Selection Dimensions of Personal Care Products

\begin{tabular}{|c|c|c|c|c|}
\hline & Factor Names & Variables & Loadings & Communalities \\
\hline \multirow{15}{*}{$\begin{array}{l}\frac{0}{0} \\
\frac{0}{\varepsilon} \\
\frac{\pi}{\pi} \\
\text { ஸ }\end{array}$} & Variety \& Value Seeking (Eigen & Multi brands & 0.824 & 0.724 \\
\hline & Value $=4.659$, Variance Explained $\%$ & Price & 0.803 & 0.707 \\
\hline & $=31.062)$ & Promotions & 0.800 & 0.664 \\
\hline & & Novelty and Variety & 0.798 & 0.700 \\
\hline & Functionality- Hair care (Eigen & Shiny hairs & 0.816 & 0.672 \\
\hline & Value $=2.810$, Variance Explained $\%$ & Freshness & 0.803 & 0.648 \\
\hline & $=18.736)$ & Fragrance & 0.792 & 0.645 \\
\hline & & Hair fall prevention & 0.726 & 0.550 \\
\hline & & Dandruff prevention & 0.680 & 0.469 \\
\hline & Brand Adherence (Eigen Value= & Brand reputation & 0.775 & 0.652 \\
\hline & 1.448, Variance Explained \% =9.655) & Quality & 0.724 & 0.597 \\
\hline & & Self image & 0.620 & 0.654 \\
\hline & & Loyalty/Price insensitiveness & 0.511 & 0.549 \\
\hline & Habitual Selection (Eigen Value $=$ & Time & 0.885 & 0.879 \\
\hline & 1.002, Variance Explained \% =6.325) & Parents & 0.856 & 0.809 \\
\hline \multirow{16}{*}{ 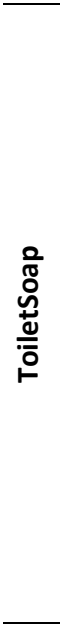 } & Value \& Variety seeking (Eigen & Promotions & 0.792 & 0.659 \\
\hline & Value $=4.704$, Explained $\%=29.399$ ) & Novelty and Variety & 0.784 & 0.651 \\
\hline & & Multi brands & 0.777 & 0.658 \\
\hline & & Price & 0.775 & 0.658 \\
\hline & & Parents & 0.502 & 0.592 \\
\hline & Functionality- Skin Care (Eigen & Fragrance & 0.766 & 0.596 \\
\hline & Value $=2.704$, Variance Explained $\%$ & Prevent disease & 0.758 & 0.595 \\
\hline & $=16.900)$ & Smooth skin & 0.756 & 0.589 \\
\hline & & Bad odor & 0.749 & 0.578 \\
\hline & & Freshness & 0.716 & 0.547 \\
\hline & Significance of Image \& Time (Eigen & Brand reputation & 0.766 & 0.609 \\
\hline & Value $=1.257$, Variance Explained \% & Time saving & 0.731 & 0.587 \\
\hline & $=7.854)$ & Self image & 0.651 & 0.593 \\
\hline & & Quality & 0.610 & 0.437 \\
\hline & Friends Influence (Eigen Value= & Friends & 0.681 & 0.755 \\
\hline & 1.001, Variance Explained \% =6.076) & $\begin{array}{l}\text { Loyalty/ Price } \\
\text { insensitiveness }\end{array}$ & 0.434 & 0.561 \\
\hline \multirow{16}{*}{ 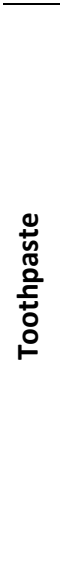 } & Functionality- Oral Care (Eigen Value $=$ & Tooth decay & 0.797 & 0.680 \\
\hline & 4.444, Variance Explained $\%=27.778$ ) & Cavity & 0.795 & 0.661 \\
\hline & & Whitening & 0.749 & 0.634 \\
\hline & & Freshness & 0.714 & 0.544 \\
\hline & & Gum protection & 0.662 & 0.472 \\
\hline & & Taste & 0.645 & 0.534 \\
\hline & Value Seeking (Eigen Value $=3.101$, & Promotion & 0.809 & 0.674 \\
\hline & Variance Explained \% =19.380) & Multi brands & 0.791 & 0.668 \\
\hline & & Price & 0.747 & 0.662 \\
\hline & & Novelty and Variety & 0.728 & 0.605 \\
\hline & Outer directed adherence (Eigen & Brand reputation & 0.777 & 0.631 \\
\hline & Value $=1.277$, Variance Explained \% & Time saving & 0.754 & 0.649 \\
\hline & $=7.984)$ & Self image & 0.537 & 0.577 \\
\hline & & Friends & 0.505 & 0.685 \\
\hline & Parental Influence (Eigen Value= & & 0.699 & 0.640 \\
\hline & 2.810, Variance Explained $\%=6.254$ ) & Loyalty/ Price insensitiveness & 0.488 & 0.508 \\
\hline
\end{tabular}




\subsection{Differences in brand selection dimensions for personal care products buyers across age and gender of buyers-Multivariate}

\subsubsection{MANOVA design}

In order to test the aforesaid hypotheses, a 2 (age) $\times 2$ (gender) MANOVA design has been prepared. Demographic variables-age and gender have been taken as independent (categorical) variables and brand selection dimension scores have been taken as dependent (continuous) variables.

\subsubsection{Results of MANOVA}

Equality of variance covariance matrices of dependent variables across the groups is depicted through Box's M test. The Box's M arrives at 39.881 with $F$ value $=1.310$ $(p=0.119)$ for shampoo, 46.123 with $F$ value $=1.515(p=0.035)$ for toilet soap and 38.435 with $F$ value $=1.262(p=0.153)$ for soap, which is insignificant.. Thus, this assumption of homogeneity of variance across groups of brand selection dimensions is satisfied. Moreover, inter-correlation between dependent variables has been checked through Bartlett's Test of Sphericity for shampoo (Chi Square= 3203.77, $d f=105$, sig.=0.000), toilet soap (Chi Square=2838.25, $d f=120$, sig.=0.000), and toothpaste (Chi Square $=2942.42, d f=120$, sig. $=0.000$ ), which justifies the use of MANOVA.

Table 2 provides a summary of group profiles (means and standard deviations) for each of the brand selection dimension across age and gender of personal care products-shampoo, toilet soap and toothpaste buyers. The results of multivariate and univariate tests are given in Table 3 and 4 respectively.

Table 2 shows the total means score differences for all three products. It reflects that male customers irrespective of age categories report to involve more in all dimensions of brand selection of personal care products (shampoo, toilet soap and toothpaste) as compared to their female counterparts. In particular, male respondents have given more weight age to variety, value seeking and functionality dimensions of brand selection of all three products. Whereas, for brand adherence of shampoo, significance of image $\&$ time, friend influence dimensions of toilet soap, female respondents report to consider these dimensions more in contrast to males. Similarly, females were more attached to two dimensions-outer directed adherence and parental influence at the time of selection of toothpaste brand.

Table 3 depicts that multivariate statistic for MANOVA is statistically significant for gender for all three products-shampoo (Wilk's lambda $=0.955, F(4,535)=6.245$, $\mathrm{p}<0.00$ ), toilet soap (Wilk's lambda $=0.961, \mathrm{~F}(4,535)=5.464, \mathrm{p}<0.00$ ) and toothpaste (Wilk's lambda $=0.963, F(4,535)=5.125, p<0.00)$. Multivariate statistic for MANOVA has reported no significance for age as well as for interaction of age and gender across any studied product. It highlights the view that the brand selection dimensions taken together differ across only gender of the personal care product buyers. 
Sakshi SHARMA \& Maninder SINGH

Table 2. Means and Standard Deviations of Brand selection for personal care product buyers across age and Gender

\begin{tabular}{|c|c|c|c|c|c|c|c|c|c|c|c|c|c|}
\hline \multirow{3}{*}{$\begin{array}{l}\frac{n}{0} \\
\frac{0}{0} \\
0 \\
\frac{0}{2}\end{array}$} & \multirow{3}{*}{ Factors } & \multicolumn{4}{|c|}{$\begin{array}{c}\text { Age } 30-40 \text { years } \\
(\mathrm{N}=195)\end{array}$} & \multicolumn{4}{|c|}{ Age $41-50$ years $(N=347)$} & \multicolumn{4}{|c|}{ Total $(\mathrm{N}=542)$} \\
\hline & & \multicolumn{2}{|c|}{$\begin{array}{l}\text { Males } \\
(\mathrm{N}=88)\end{array}$} & \multicolumn{2}{|c|}{$\begin{array}{l}\text { Females } \\
(\mathrm{N}=107)\end{array}$} & \multicolumn{2}{|c|}{$\begin{array}{c}\text { Males } \\
(N=171)\end{array}$} & \multicolumn{2}{|c|}{$\begin{array}{l}\text { Females } \\
(\mathrm{N}=176)\end{array}$} & \multicolumn{2}{|c|}{$\begin{array}{c}\text { Males } \\
(\mathrm{N}=259)\end{array}$} & \multicolumn{2}{|c|}{$\begin{array}{l}\text { Females } \\
(\mathrm{N}=283)\end{array}$} \\
\hline & & Mean & SD & Mean & SD & Mean & SD & Mean & SD & Mean & SD & Mean & SD \\
\hline \multirow{4}{*}{ 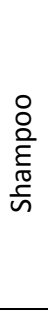 } & $\begin{array}{l}\text { Variety \& } \\
\text { Value Seeking }\end{array}$ & 2.99 & 0.95 & 2.58 & 0.99 & 2.82 & 1.03 & 2.54 & 0.81 & 2.88 & 1.01 & 2.55 & 0.88 \\
\hline & $\begin{array}{l}\text { Functionality- } \\
\text { Hair care }\end{array}$ & 4.07 & 0.64 & 3.91 & 0.65 & 3.98 & 0.60 & 3.97 & 0.56 & 4.01 & 0.61 & 3.95 & 0.60 \\
\hline & $\begin{array}{l}\text { Brand } \\
\text { Adherence }\end{array}$ & 3.87 & 0.70 & 4.04 & 0.76 & 3.87 & 0.73 & 4.12 & 0.62 & 3.87 & 0.72 & 4.09 & 0.68 \\
\hline & $\begin{array}{l}\text { Habitual } \\
\text { Selection }\end{array}$ & 2.75 & 1.12 & 2.73 & 1.13 & 2.79 & 1.19 & 2.73 & 1.18 & 2.78 & 1.16 & 2.73 & 1.16 \\
\hline \multirow{4}{*}{$\begin{array}{l}\frac{0}{\pi} \\
0 \\
0 \\
\frac{1}{\overline{0}} \\
\frac{0}{0}\end{array}$} & $\begin{array}{l}\text { Value \& } \\
\text { Variety } \\
\text { seeking }\end{array}$ & 2.95 & 0.64 & 2.68 & 0.70 & 2.89 & 0.69 & 2.68 & 0.58 & 2.91 & 0.68 & 2.68 & 0.63 \\
\hline & $\begin{array}{l}\text { Functionality- } \\
\text { Skin Care }\end{array}$ & 4.00 & 0.68 & 3.93 & 0.57 & 3.99 & 0.61 & 4.03 & 0.53 & 3.99 & 0.63 & 3.99 & 0.55 \\
\hline & $\begin{array}{l}\text { Sig. of Image } \\
\text { \& Time }\end{array}$ & 3.80 & 0.74 & 3.88 & 0.68 & 3.78 & 0.72 & 3.97 & 0.61 & 3.78 & 0.72 & 3.94 & 0.64 \\
\hline & $\begin{array}{l}\text { Friends } \\
\text { Influence }\end{array}$ & 3.05 & 0.67 & 3.14 & 0.60 & 3.09 & 0.70 & 3.23 & 0.62 & 3.08 & 0.68 & 3.19 & 0.61 \\
\hline \multirow{4}{*}{ 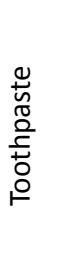 } & $\begin{array}{l}\text { Functionality- } \\
\text { Oral Care }\end{array}$ & 3.34 & 0.42 & 3.32 & 0.60 & 3.35 & 0.48 & 3.32 & 0.49 & 3.35 & 0.46 & 3.32 & 0.48 \\
\hline & Value Seeking & 2.99 & 0.92 & 2.66 & 0.95 & 2.90 & 1.00 & 2.57 & 0.80 & 2.95 & 0.97 & 2.60 & 0.86 \\
\hline & $\begin{array}{l}\text { Outer directed } \\
\text { adherence }\end{array}$ & 3.31 & 0.56 & 3.36 & 0.52 & 3.27 & 0.55 & 3.44 & 0.49 & 3.20 & 0.56 & 3.41 & 0.50 \\
\hline & $\begin{array}{l}\text { Parental } \\
\text { Influence }\end{array}$ & 3.16 & 0.90 & 3.41 & 0.83 & 3.30 & 0.98 & 3.57 & 0.88 & 3.25 & 0.95 & 3.50 & 0.86 \\
\hline
\end{tabular}

Table 3. Summary of Multivariate test associated with brand selection for personal care products

\begin{tabular}{cccccccc}
\hline Products & Effects & $\begin{array}{c}\text { Wilks' lambda } \\
\text { Value }\end{array}$ & F & Df & Error df & Significance & $\begin{array}{c}\text { Observed } \\
\text { power }\end{array}$ \\
\hline Shampoo & Age & 0.997 & 0.449 & 4 & 535 & 0.773 & 0.156 \\
\cline { 2 - 8 } & Gender & 0.955 & 6.245 & 4 & 535 & $0.000^{*}$ & 0.989 \\
\cline { 2 - 8 } & Age-Gender & 0.992 & 1.075 & 4 & 535 & 0.368 & 0.340 \\
\hline Toilet Soap & Age & 0.996 & 0.537 & 4 & 535 & 0.708 & 0.181 \\
\cline { 2 - 8 } & Gender & 0.961 & 5.464 & 4 & 535 & $0.000^{*}$ & 0.976 \\
\cline { 2 - 8 } & Age-Gender & 0.995 & 0.643 & 4 & 535 & 0.632 & 0.211 \\
\hline Toothpaste & Age & 0.994 & 0.853 & 4 & 535 & 0.492 & 0.273 \\
\cline { 2 - 8 } & Gender & 0.963 & 5.125 & 4 & 535 & $0.000^{*}$ & 0.967 \\
\cline { 2 - 8 } & Age-Gender & 0.997 & 0.467 & 4 & 535 & 0.760 & 0.161 \\
\hline
\end{tabular}

*Significant at $1 \%$ level 
Further, the results of univariate test of group differences in brand selection dimensions across age and gender of personal care products buyers have been examined through F-ratio as shown in table 4. They have been explained thereafter.

Table 4. Latent Variable Correlations and Square Roots of AVEs

\begin{tabular}{|c|c|c|c|c|c|c|c|c|c|}
\hline $\mathrm{H}$ & IV & DV & $\begin{array}{l}\text { Sum of } \\
\text { Squares }\end{array}$ & df & $\begin{array}{l}\text { Mean } \\
\text { Square }\end{array}$ & $\mathbf{F}$ & Sig. & $\begin{array}{c}\text { Observed } \\
\text { power }\end{array}$ & Result \\
\hline \multicolumn{10}{|c|}{ Shampoo } \\
\hline \multirow{4}{*}{ H1 } & \multirow{4}{*}{ Age } & $\begin{array}{l}\text { Variety \& Value } \\
\text { Seeking }\end{array}$ & 1.441 & 1 & 1.441 & 1.605 & 0.206 & 0.244 & Rejected \\
\hline & & $\begin{array}{l}\text { Functionality- Hair } \\
\text { care }\end{array}$ & 0.033 & 1 & 0.033 & 0.089 & 0.766 & 0.060 & Rejected \\
\hline & & Brand Adherence & 0.227 & 1 & 0.227 & 0.459 & 0.498 & 0.104 & Rejected \\
\hline & & Habitual Selection & 0.057 & 1 & 0.057 & 0.042 & 0.838 & 0.055 & Rejected \\
\hline \multirow{4}{*}{ H2 } & \multirow{4}{*}{ Gender } & $\begin{array}{l}\text { Variety \& Value } \\
\text { Seeking }\end{array}$ & 14.919 & 1 & 14.919 & 16.611 & $0.000 *$ & 0.983 & Accepted \\
\hline & & $\begin{array}{l}\text { Functionality- Hair } \\
\text { care }\end{array}$ & 0.941 & 1 & 0.941 & 2.532 & 0.112 & 0.355 & Rejected \\
\hline & & Brand Adherence & 5.548 & 1 & 5.548 & 11.199 & $0.001 *$ & 0.916 & Accepted \\
\hline & & Habitual Selection & 0.184 & 1 & 0.184 & 0.135 & 0.713 & 0.066 & Rejected \\
\hline \multirow{4}{*}{ H3 } & \multirow{4}{*}{$\begin{array}{l}\text { Age } X \\
\text { gender }\end{array}$} & $\begin{array}{l}\text { Variety \& Value } \\
\text { Seeking }\end{array}$ & 0.545 & 1 & 0.545 & 0.607 & 0.436 & 0.122 & Rejected \\
\hline & & $\begin{array}{l}\text { Functionality- Hair } \\
\text { care }\end{array}$ & 0.763 & 1 & 0.763 & 2.053 & 0.152 & 0.299 & Rejected \\
\hline & & Brand Adherence & 0.191 & 1 & 0.191 & 0.385 & 0.535 & 0.095 & Rejected \\
\hline & & Habitual Selection & 0.055 & 1 & 0.055 & 0.041 & 0.840 & 0.055 & Rejected \\
\hline \multicolumn{10}{|c|}{ Toilet soap } \\
\hline \multirow{4}{*}{ H4 } & \multirow{4}{*}{ Age } & $\begin{array}{l}\text { Value \& Variety } \\
\text { seeking }\end{array}$ & 0.093 & 1 & 0.093 & 0.216 & 0.642 & 0.075 & Rejected \\
\hline & & $\begin{array}{l}\text { Functionality- Skin } \\
\text { Care }\end{array}$ & 0.259 & 1 & 0.259 & 0.735 & 0.392 & 0.137 & Rejected \\
\hline & & $\begin{array}{l}\text { Sig. of Image \& } \\
\text { Time }\end{array}$ & 0.152 & 1 & 0.152 & 0.321 & 0.571 & 0.087 & Rejected \\
\hline & & Friends Influence & 0.568 & 1 & 0.568 & 1.330 & 0.249 & 0.210 & Rejected \\
\hline \multirow{4}{*}{ H5 } & \multirow{4}{*}{ Gender } & $\begin{array}{l}\text { Value \& Variety } \\
\text { seeking }\end{array}$ & 7.058 & 1 & 7.058 & 16.354 & $0.000^{*}$ & 0.981 & Accepted \\
\hline & & $\begin{array}{l}\text { Functionality-Skin } \\
\text { Care }\end{array}$ & 0.024 & 1 & 0.024 & 0.068 & 0.795 & 0.058 & Rejected \\
\hline & & $\begin{array}{l}\text { Sig. of Image \& } \\
\text { Time }\end{array}$ & 2.424 & 1 & 2.424 & 5.132 & $0.024 * *$ & 0.618 & Accepted \\
\hline & & Friends Influence & 1.459 & 1 & 1.459 & 3.416 & $0.065^{* * *}$ & 0.454 & Accepted \\
\hline \multirow{4}{*}{ H6 } & \multirow{4}{*}{$\begin{array}{l}\text { Age } X \\
\text { gender }\end{array}$} & $\begin{array}{l}\text { Value \& Variety } \\
\text { seeking }\end{array}$ & 0.081 & 1 & 0.081 & 0.187 & 0.665 & 0.072 & Rejected \\
\hline & & $\begin{array}{l}\text { Functionality- Skin } \\
\text { Care }\end{array}$ & 0.390 & 1 & 0.390 & 1.107 & 0.293 & 0.183 & Rejected \\
\hline & & $\begin{array}{l}\text { Sig. of Image \& } \\
\text { Time }\end{array}$ & 0.421 & 1 & 0.421 & 0.891 & 0.346 & 0.156 & Rejected \\
\hline & & Friends Influence & 0.078 & 1 & 0.078 & 0.183 & 0.669 & 0.071 & Rejected \\
\hline
\end{tabular}


Sakshi SHARMA \& Maninder SINGH

Table 4 (Cont.)

\begin{tabular}{|c|c|c|c|c|c|c|c|c|c|}
\hline $\mathrm{H}$ & IV & DV & $\begin{array}{l}\text { Sum of } \\
\text { Squares }\end{array}$ & df & $\begin{array}{l}\text { Mean } \\
\text { Square }\end{array}$ & $\mathbf{F}$ & Sig. & $\begin{array}{c}\text { Observed } \\
\text { power }\end{array}$ & Result \\
\hline \multicolumn{10}{|c|}{ Toothpaste } \\
\hline \multirow{4}{*}{ H7 } & \multirow{4}{*}{ Age } & $\begin{array}{l}\text { Functionality- } \\
\text { Oral Care }\end{array}$ & 0.003 & 1 & 0.003 & 0.013 & 0.909 & 0.051 & Rejected \\
\hline & & Value Seeking & 0.675 & 1 & 0.675 & 0.795 & 0.373 & 0.145 & Rejected \\
\hline & & $\begin{array}{l}\text { Outer directed } \\
\text { adherence }\end{array}$ & 0.051 & 1 & 0.051 & 0.179 & 0.673 & 0.071 & Rejected \\
\hline & & $\begin{array}{l}\text { Parental } \\
\text { Influence }\end{array}$ & 2.636 & 1 & 2.636 & 3.175 & $0.075^{* *}$ & 0.428 & Accepted \\
\hline \multirow{4}{*}{ H8 } & \multirow{4}{*}{ Gender } & $\begin{array}{l}\text { Functionality- } \\
\text { Oral Care }\end{array}$ & 0.070 & 1 & 0.070 & 0.314 & 0.576 & 0.087 & Rejected \\
\hline & & Value Seeking & 14.669 & 1 & 14.669 & 17.278 & $0.000^{*}$ & 0.986 & Accepted \\
\hline & & $\begin{array}{l}\text { Outer directed } \\
\text { adherence }\end{array}$ & 1.671 & 1 & 1.671 & 5.838 & $0.016^{* *}$ & 0.674 & Accepted \\
\hline & & $\begin{array}{l}\text { Parental } \\
\text { Influence } \\
\end{array}$ & 8.419 & 1 & 8.419 & 10.139 & $0.002^{*}$ & 0.888 & Accepted \\
\hline \multirow{4}{*}{ H9 } & \multirow{4}{*}{$\begin{array}{l}\text { Age } X \\
\text { gender }\end{array}$} & $\begin{array}{l}\text { Functionality- } \\
\text { Oral Care }\end{array}$ & 0.005 & 1 & 0.005 & 0.021 & 0.884 & 0.052 & Rejected \\
\hline & & Value Seeking & 0.014 & 1 & 0.014 & 0.017 & 0.897 & 0.052 & Rejected \\
\hline & & $\begin{array}{l}\text { Outer directed } \\
\text { adherence }\end{array}$ & 0.438 & 1 & 0.438 & 1.529 & 0.217 & 0.235 & Rejected \\
\hline & & $\begin{array}{l}\text { Parental } \\
\text { Influence }\end{array}$ & 0.011 & 1 & 0.011 & 0.013 & 0.909 & 0.051 & Rejected \\
\hline
\end{tabular}

*Significant at $1 \%$ level, **Significant at 5\% level, ***Significant at $10 \%$ level

Differences by age of personal care product buyers: The results indicate that no significant difference exists in brand selection dimensions of personal care products across age categories for all products i.e. shampoo, toilet soap and toothpaste. For shampoo, the $\mathrm{p}$ values for brand selection dimensions - Variety and Value seeking, Functionality-Hair care, Band Adherence and Habitual selection are 0.206, 0.766, 0.498 and 0.838 respectively. For toilet soap, the $p$ values for brand selection dimensions-Value and Variety Seeking, Functionality-Skin Care, Significance for Image \& Time and Friend's Influence are $0.642,0.392,0.571$ and 0.249 respectively. Similarly, the $\mathrm{p}$ values of toothpaste brand selection dimensions-FunctionalityOral care, Value seeking, Outer Directed Adherence are 0.909, 0.373 and 0.673 respectively with an exception of Parental Influence dimension ( $p$ value $<0.075$ ) which is statistically significant.

Differences by gender of personal care product buyers: Results reveals that for shampoo in two brand selection dimensions - Variety and Value seeking $(p<0.000)$ and Band Adherence $(p<0.001)$, significant differences exist across male and female buyers whereas, no significant differences has been observed for remaining two dimensions-Habitual selection $(p=0.713)$ and Functionality-Hair care $(p=0.112)$.Further, for toilet soap, the $p$ values for all brand selection dimensions - 
Value and Variety seeking $(p<0.000)$, Significance for Image \& Time $(p<0.024)$ and friend's Influence $(p<0.065)$ except Functionality- Oral care $(p=0.795)$ reveal significant differences across gender.

Similarly, for toothpaste, the $p$ values of all brand selection dimensions-Value seeking $(p<0.000)$, Outer Directed Adherence $(p<0.016)$ and Parental influence dimension ( $p$ value $<0.002$ ) except Functionality- Oral care $(p=0.576)$, expose significant differences across male and females buyers.

Differences by interaction of age and gender of personal care product buyers: The results indicate that no significant difference exists in interaction of age and gender of respondents across brand selection dimensions of personal care products i.e. shampoo $(0.436,0.152,0.535$ and 0.840$)$, toilet soap $(0.665,0.293,0.346$ and 669$)$ and toothpaste $(0.884,0.897,0.217$ and 0.909$)$.

\subsubsection{Hypotheses Testing}

Thus out of nine hypotheses, three hypotheses $-\mathrm{H} 2, \mathrm{H} 5$ and $\mathrm{H} 8$ have been partially accepted and six hypotheses- $\mathrm{H} 1, \mathrm{H} 3, \mathrm{H} 4, \mathrm{H} 6, \mathrm{H} 7$ and $\mathrm{H} 9$ are rejected, meaning thereby that study found significant differences across gender with respect to brand selection dimensions of personal care products (shampoo, toilet soap and toothpaste). In contrast, no significant differences are depicted with respect to age as well as interaction of age and gender as regards brand selection dimensions of personal care products.

\section{Findings}

Comparison of brand selection dimensions solutions of personal care products demonstrates that while selecting shampoo and toilet soap, value and variety are found to be the strongest dimensions followed by functionality dimension. In opposite to this, while selecting toothpaste; functionality has been the strongest dimension of brand selection followed by value seeking dimension. Lastly it was observed that habitual selection is considered an important dimension of brand selection of shampoo, whereas at the time of brand selection of toilet soap and toothpaste, friend's influence and parent's influence respectively found to be important dimensions. Moreover, a comparison drawn on the basis of the results obtained from multivariate analysis of variance (MANOVA) reveal that overall, significant difference are observed in males and females across brand selection dimensions irrespective of their ages. Interestingly, it has been found that functionality dimension was not only considered important in all studied products, moreover, no gender differences are observed in this brand dimension (functionality)for all personal care products. It indicates that for both-males and females, functional aspects of the personal care products are almost similarly important. Therefore it can be concluded that male and females may select personal care products due to different brand selection dimensions but functionality plays important role in brand selection behaviour of both. 


\section{Discussion, Conclusions and Implications}

The primary aim of this study was to examine the brand selection dimensions of buyers of personal care products related to hair care (shampoo), skin care (toilet soaps) and oral care (toothpaste). Based on the previous literature of brand selection, the study revealed four brand selection dimensions for each product i.e. shampoo(Variety and Value seeking, Functionality-Hair care, Brand Adherence and Habitual Selection), toilet soap (Value \& Variety seeking, Functionality, Significance of Image and Time and friends influence)and toothpaste (Functionality-Oral Care, Value Seeking, Outer Directed Brand Adherence and Parental Influence). The factor structure as outlined in the study goes in line with some previous studies (Tifferet and Herstein, 2012; Gasiorowska, 2011; Wood, 2004 \& 2007; Leong, 1993). Interestingly, this study shows that males are found to be more variety, value and functionality seekers of personal care products as compared to their counterparts. This finding oppose the results of some other researchers suggesting that in selection of basic goods, males are found to be less involved in variety and value seeking and prefer repeating their brand. (Bakewell \& Mitchel, 2004). Females are found to be more brands adhered and influenced by friend and parents. Furthermore, the present study reinforce that though branding has become a means of differentiation in fast moving consumer goods market, still the significance of functional aspects of products should not be ignored in favor of symbolic aspects in product management of personal care products. Moreover, the variety and value seeking brand selection dimension exhibited by the customers suggests that even image of brand is an important aspect of brand selection in this market, still promotional efforts like sales promotion and advertising can play a vital role in market of this product category for the new entrants. Established marketers can also add variety in their portfolio to retain their present variety seeking customers or can attract new customers by providing more value for money.

\section{Limitations and Directions for Future Research}

The present study is based on the personal care products buyers in India and confined to uncover brand selection dimensions of only one personal care product from each category-hair care (shampoo), skin care (toilet soap) and oral care (toothpaste). Future research might seek brand selection dimensions with different products (e.g. hair conditioner, hair oil, skin creams, moisturizers, mouthwash, tongue cleaners etc.) and categories (e.g. hygiene care, nail care etc.) of personal care products. Moreover, in this study the responses of either spouse have been studied. In future, brand selection dimension of personal care products can be observed and compared by studying the individual responses of each family member. Longitudinal research may be undertaken to gauge the changes in customer's brand selection dimensions of personal care products in long run. 


\section{References}

Bakewell, C., \& Mitchell, V. W. (2004). Male Consumer Decision-Making Styles. The International Review of Retail, Distribution and Consumer Research, 14(2), 223-240. https://doi.org/10.1080/0959396042000178205

Barber, N., Almanza, B. A., \& Donovan, J. R. (2006). Motivational Factors of Gender, Income and Age on Selecting a Bottle of Wine. International Journal of Wine Marketing, 18(3), 218232. https://doi.org/10.1108/09547540610704774

Beatty, S. E., \& Talpade, S., (1994), Adolescent Influence in Family Decision Making: A Replication with Extension. Journal of Consumer Research, 21(2), 332-341. https://doi.org/10.1086/209401

Bhat, S., \& Reddy, S. K. (1998). Symbolic and Functional Positioning of Brands. Journal of Consumer Marketing, 15(1), 32-43. https://doi.org/10.1108/07363769810202664

Bristol, T. (2001). Understanding the adolescent's Consumption World: Shopping, Influencing, Deceiving. Advances in Consumer Research, 28(1), 16-19.

Burns, A. C., \& Granbois, D. H. (1980). Advancing the Study of Family Purchase Decision Making. Advances in Consumer Research, 7(1), 221-226. Retrieved from: http://acrwebsite.org/volumes/9235/volumes/v07/NA-07

Carmen, J. M. (1970). Correlates of Brand Loyalty. Journal of Marketing Research, 7(1), 6776. https://doi.org/10.1177/002224377000700108

Copeland, M.T., (1923). Relation of Consumer's Buying Habits to Marketing Method. Harvard Business Review, 1, 282-9.

Cunha, R. D. A. N., \& Neto, P. J. S. (2015). The Adolescent Influence in Family DecisionMaking: Parents Perception. International Business Research, 8(5), 244. http://dx.doi.org/10.5539/ibr.v8n5p244

Cunningham, R. M. (1956). Brand Loyalty-What, Where, How Much. Harvard Business Review, 34(1), 116-128.

Davis, H. L. (1976). Decision Making Within the Household. Journal of Consumer Research, 2(4), 241-260. https://doi.org/10.1086/208639

Davis, H.L. (1970). Dimensions of marital roles in consumer decision making. Journal of Marketing Research, 7(2), 168-177. https://doi.org/10.1177/002224377000700203

Davis, H.L., (1971). Measurement of Husband-wife Influence in Consumer Purchase Decisions. Journal of Marketing Research, 8(3), 305-312. https://doi.org/10.1177/002224377100800304

Deshpande, R., Hoyer, W. D., \& Jeffries, S. (1982). Low Involvement Decision Processes: The Importance of Choice Tactics. Marketing theory: Philosophy of science perspectives, 155-158.

Dholakia, R.R. (1999). Going Shopping: Key Determinants of Shopping Behaviors and motivations. International Journal of Retail and Distribution Management, 27(4), 154-166. https://doi.org/10.1108/09590559910268499

Ferber, R., \& Chao Lee, L. (1974). Husband-Wife Influence in Family Purchasing Behavior. Journal of Consumer Research, 1(1), 43-50. https://doi.org/10.1086/208580

Gasiorowska, A. (2003). The Model of Structure, Determinant and Behavioural Consequences of Impulsive Buying. Unpublished doctoral dissertation, Wroclaw: Wroclaw University of Technology. 
Gąsiorowska, A. (2011). Gender as a Moderator of Temperamental Causes of Impulse Buying Tendency. Journal of Customer Behaviour, 10(2), 119-142. https://doi.org/10.1362/147539211X589546

Harcar, T., Spillan, J. E., \& Kucukemiroglu, O. (2005). A Multi-National Study of Family Decision-Making. Multinational Business Review, 13(2), 3-21. https://doi.org/10.1108/1525383X200500006

Jacoby, J., \& Chestnut, R. W. (1978). Brand Loyalty, Measurement and Management. Journal of Advertising, 8 (2), $120 . \quad$ New York: John Wiley \& Sons. https://doi.org/10.1080/00913367.1979.10717981

Jenkins, R. L. (1980). Contributions of Theory to the Study of Family Decision-Making. Advances in Consumer Research, 7(1), 207-211. Retrieved from: http://acrwebsite.org/volumes/9232/volumes/v07/NA-07

Kollat, D.T., \& Willet, R.P. (1967). Customer Impulse Purchasing Behavior. Journal of Marketing Research, 4, 21-31. Retrieved from: https://www.jstor.org/stable/3150160. https://doi.org/10.2307/3150160

Lee, C.K.C. and Beatty, S.E. (2002), Family Structure and Influence in Family Decision-Making, Journal of Consumer Marketing, 19 (1), 24-41. https://doi.org/10.1108/07363760210414934

Lee, J. (2018). Factor Analysis on Brand Recognition and Image Purchases. Journal of Research in Marketing, 9(2), 723-732. Retrieved from: http://www.jormonline.com/index.php/jorm/article/view/238.

Leong, S. M. (1993). Consumer Decision Making for Common, Repeat-Purchase Products: A Dual Replication. Journal of Consumer Psychology, 2(2), 193-208. https://doi.org/10.1016/S1057-7408(08)80024-1

Ministry of Women and Child Development, Government of India (2013-14). Rapid Survey on Children, assessed on August 23, 2018, retrieved from http://wcd.nic.in/sites/default/files/State\%20RSOC.pdf

Mise, J. K., Nair, C., Odera, O., \& Ogutu, M. (2013). Exploring the Determinants of Brand Loyalty in Global FMCG Markets of Soft Drinks Consumers in Kenya and India, International Journal of Research in Management 3(2), 1-15.

Palumbo, F., \& Herbig, P. (2000). The Multicultural Context of Brand Loyalty. European Journal of Innovation Management, 3(3), 116-125. https://doi.org/10.1108/14601060010334876

Park, C. W., Jaworski, B. J., \& Maclnnis, D. J. (1986). Strategic Brand Concept-Image Management. The Journal of Marketing, 50 (4), 135-145. https://doi.org/10.1177\%2F002224298605000401

Pradhan, M. J., \& Misra, D. P (2015). Rural Brand Awareness and Preferences for FMCGs: An Empirical Study on Keonjhar District of Odisha, India. IOSR Journal of Business and Management, 16(9), 17-29.

Ramesh Kumar, S., \& Advani, J. Y. (2005). Factors Affecting Brand Loyalty: A Study in An Emerging Market on Fast Moving Consumer Goods. Journal of Customer Behaviour, 4(2), 251-275. https://doi.org/10.1362/1475392054797223

Rishi, B. (2013). Determinants of Brand Trust for FMCG Products with Special Reference to Shampoos Category. Asia-Pacific Journal of Management Research and Innovation, 9(2), 221227. https://doi.org/10.1177\%2F2319510X13504338 
Rundle-Thiele, S., \& Bennett, R. (2001). A Brand for All Seasons? A Discussion of Brand Loyalty Approaches and their Applicability for Different Markets. Journal of Product \& Brand Management, 10(1), 25-37. https://doi.org/10.1108/10610420110382803

Soni, P. (2004). Role-Structures in the Buying Decision Process for Durables. Paradigm, 8(1), 63-80. https://doi.org/10.1177\%2F0971890720040108

Spiro, R. (1983). Persuasion in Family Decision-Making. Journal of Consumer Research, 9(4), 393-402. http://dx.doi.org/10.1086/208933

Szybillo, G. J., \& Sosanie, A. (1977). Family Decision Making: Husband, Wife and Children. Advances in Consumer Research, 4, 46-49. Retrieved from: http://acrwebsite.org/volumes/9327/volumes/v04/NA-04

Thomson, E., Laing, A., \& McKee, L. (2007). Family Purchase Decision Making: Exploring Child Influence Behavior! Journal of Consumer Behaviour, 6(4), 182-202. https://doi.org/10.1002/cb.220

Tifferet, S., \& Herstein, R. (2012). Gender Differences in Brand Commitment, Impulse Buying, and Hedonic Consumption. Journal of Product \& Brand Management, 21(3), 176-182. https://doi.org/10.1108/10610421211228793

Wang, S., Holloway, B. B., Beatty, S. E., \& Hill, W. W. (2007). Adolescent Influence in Family Purchase Decisions: An Update and Cross-National Extension. Journal of Business Research, 60(11), 1117-1124. https://doi.org/10.1016/j.jbusres.2007.04.004

Watne, T., \& Brennan, L. (2011). Behavioral Change Starts in The Family: The Role of Family Communication and Implications for Social Marketing. Journal of Nonprofit \& Public Sector Marketing, 23(4), 367-386. http://dx.doi.org/10.1080/10495142.2011.623526

Wheeler, D. R. (1974). Brand Loyalties: Qualitative, Quantitative, or Both? Journal of the Academy of Marketing Science, 2(1-4), 651-658. https://doi.org/10.1177\%2F009207037400200149

Wood, L. (2004). Dimensions of Brand Purchasing Behaviour: Consumers in the 18-24 Age Group. Journal of Consumer Behaviour, 4(1), 9-24. https://doi.org/10.1002/cb.154

Wood, L. (2007). Functional and Symbolic Attributes of Product Selection. British food Journal, 109(2), 108-118.https://doi.org/10.1108/00070700710725482

Wu, K., Holmes, K., \& Tribe, J. (2010). Where Do You Want To Go Today? An Analysis Of Family Group Decisions to Visit Museums. Journal of Marketing Management, 26(7), 706726. http://dx.doi.org/10.1080/02672571003780007

Yakup, D., \& Sevil, Z. (2011). An Impirical Study on the Effect of Family Factor on Consumer Buying Behaviours. Asian Social Science, 7(10), 53-62. http://dx.doi.org/10.5539/ass.v7n10p53. 